\title{
PROBLEMATIC ASPECTS OF TECHNOLOGY EDUCATION IN SLOVAKIA
}

\begin{abstract}
In current technology-based societies, understanding fundamental scientific concepts and theories and the ability to structure and solve scientific problems are more important than ever before. Understanding of science and technology is central to young people's readiness for their life in the current society. Moreover, each society, not only the technology-based one, needs creative technicians and engineers. That is why technology education has long been an integral part of (school) education although various societies and countries carry out this type of education in different ways. The paper presents the results of various researches and studies aimed at the current development and quality of technology education done mainly at lower secondary schools in Slovakia where technology education was taught within the school subject of the same name - technology education before the school reform (2008), while currently it is taught as part of the school subject called technology. The paper focuses its attention on analyses and discussions of the most problematic aspects of this development.
\end{abstract}

Keywords: Technology education, school subject technology, lower level of secondary schools (ISCED 2), quality assurance of the education.

\section{Introduction}

Technology education can in general be defined as the study of various types of techniques and technologies with the aim to develop and acquire practical skills, attitudes, understanding and knowledge related to technical occupations in relevant sectors of economic and social life. Technology education offers children and young people challenges how to make sense of the acquired theoretical knowledge and to realise the link between the theoretical subjects taught at school and technical products they come across in everyday life. Moreover, it serves as a means of preparation for an occupational career because it offers a specialised training for initial employment.

Before 1995 technology education in Slovakia was a part of the school subject called work education. In 1996 this subject was modified to subject called technical education, followed by yet another change introduced by the curricular reform in 2008. Technology education at schools (ISCED 2) has since then been taught predominantly within the school subject called technology. In the technology-based society, which we are currently indisputably living in, one would logically expect science and technology education to be prioritised in primary and secondary schools, and students to be interested in continuing their career education in various technical study fields. But the opposite is true. For quite a long time we have been witnessing that science, technology and engineering study fields have been the least favoured disciplines and students have not been keen on studying them.

\section{Interest of the youth in STEM subjects}

In the Slovak education system physics, chemistry, biology and mathematics have been considered as science education, but very often informatics together with technology have also been incorporated into the content of this term. To avoid ambiguity in the use of the terms technology education and informatics education, the acronym STEM becomes more frequently used instead of the term science / natural sciences. In this way, we follow the approach adopted by West European countries where the term STEM education has already been successfully established as the official acronym for education in science, technology, engineering and sciences.

Natural sciences and school subjects related to technology have not been very popular school subjects not only in Slovakia but world-wide for a long time. The problem of a declining interest in science and technology studies has been reported by most of the OECD countries. That is why the Global Science Forum was

\footnotetext{
* ${ }^{1}$ Alena Haskova, ${ }^{1}$ Silvia Mandulakova, ${ }^{2}$ Dirk Van Merode

${ }^{1}$ Faculty of Education, Constantine the Philosopher University in Nitra, Slovakia

${ }^{2}$ Technology and Design, Campus de Nayer, Thomas More Mechelen-Antwerpen University College, Sint-Katelijne-Waver, Belgium

E-mail: ahaskova@ukf.sk
} 
addressed to validate these findings and analyse the reasons of this state. The results of the investigation proved that the problem of low interest in STEM subjects and STEM-related careers among the youth is particularly acute in West European countries though the demand for science and technology graduates significantly grows there. In contrast to this situation, in many African and Middle East countries the interest of the youth in STEM is very high, but the quality of STEM teaching is at a low level there ([1] and [2]).

A survey which we carried out among grammar school students in Nitra region showed that common belief of unpopularity of the STEM subjects is not fully true and the situation is not so "singlecoloured" (Fig. 1).

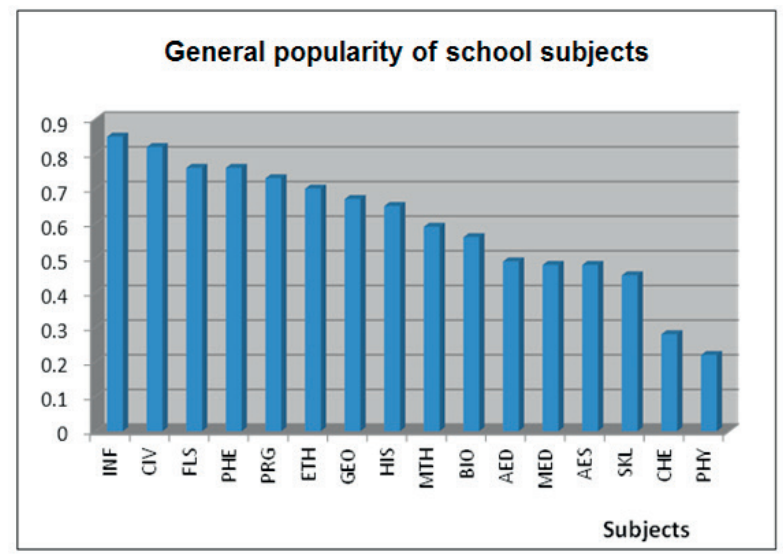

Fig. 1 General popularity of school subjects among grammar school students Abbreviations: INF - Informatics, CIV - Civics, FLS - Foreign Languages, PHE - Physical Education, PRG - Programming, ETH - Ethics / Religion, GEO - Geography, MTH - Maths, BIO - Biology, AED - Art Education, MED - Music Education, AES - Aesthetics, SKL Slovak Language, CHE - Chemistry PHY - Physics (Source: [3])

The results of the survey can be summarised in the following main findings:

- Statements about unpopularity of STEM subjects and lack of students' interest in them were confirmed in the case of chemistry and physics. The subjects related to computer sciences (informatics and programming) were identified as the most popular ones (informatics - the average coefficient of its general popularity 0.85 , programming -0.73 ). The disputability of this finding is commented below in the context of young people's interests.

- Maths, which is, together with chemistry and physics, generally perceived as one of the least popular subjects, was ranked approximately in the middle of the "popularity rate". A very interesting finding in this context is the popularity position of the mother tongue (Slovak language). The obtained data rank is at the same level of popularity where the science subjects are (chemistry and physics, the average coefficients of their general popularity being 0.28 and 0.22 respectively).

- Another popular myth claims that the lack of popularity of particular school subjects has its roots in students' learning failures. But according to the statistics of the State school inspection, the highest number of exam retakes to continue studies in a higher grade of school education are usually from foreign languages, which are perceived as a very popular school subject, while in the case of physics and chemistry, the least popular subjects, the number of these exams is quite low.

\section{Interest of the youth in STEM related careers}

There is a broad spectrum of phenomena which influence personal choice of a study field. They range from family backgrounds through school experiences up to one's salary expectations. Furthermore, the choice of the study field is influenced by many social aspects too (in relation to the choice of science and technology related professional career these can reflect, e.g. status of science and technology in the society, image of science and technology professions, teacher training and continuing professional development).

The scheme of the three main categories of key factors determining students' career interest, motivation and choice is presented in Fig. 2.

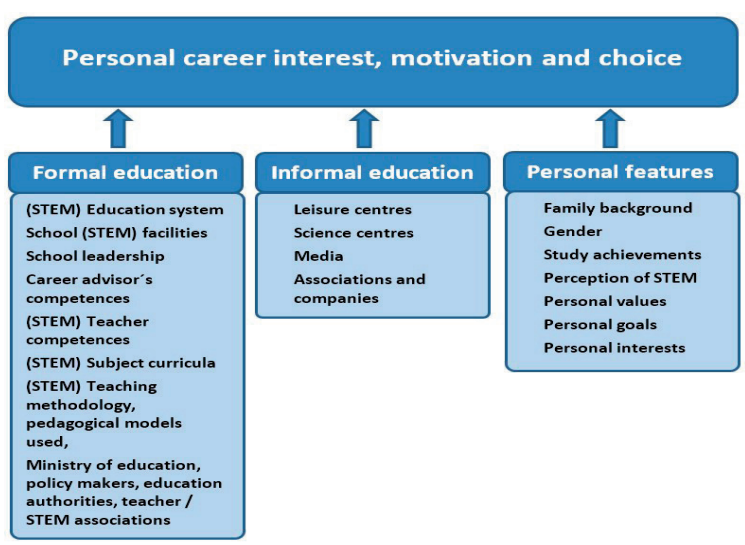

Fig. 2 Key factors determining personal career interest, motivation and choice

The research results show that the young generation has surprisingly quite a positive attitude towards science and technology, bearing in mind their contribution to making the life of the youth better and easier ([4] and [5]). But, on the other hand, they find the image of science and technology professions to a great extent negative. This is connected with the image of science and technology in the society and the values preferred by the society. Significant changes in young people's values were identified in Eurobarometer 2006 [6], but none of them is in favour of STEM. Some of the young people reject materialism, 
give priority to personal development and private life over work and they are reluctant to accept heavy workloads, such as those connected with STEM studies and careers. Others prioritise career and money, but prefer business studies, economics, law or medical studies; they do not perceive science and technology rewarding enough. Moreover, the interests of the youth differ more and more from those of the society needs (compare, for example, with [7], [8] or [9]).

In order to be interested in technology or engineering professions and choose them for their future careers, students have to be positive about technology and activities connected with technology, having a well "developed technology thinking". The beginning of formation of these personal features and the deepening of one's interest in science and technology professions (based on the acquired personal features) should therefore happen much earlier than at higher levels of education (ISCED 3, ISCED 4). Then it is too late. Technology education should already be introduced in primary and lower secondary education. But, as Phang et al. point out [10], one of the most significant reasons for the falling student enrolment in STEM study programmes is that they are turned off by the way these subjects are taught at schools. Students find studying science too difficult, boring, not worth the effort and not attractive enough for their everyday lives. Moreover, there is an evidence that many curricula are "over-stuffed" with factual content and too many added topics while only a few of them have been removed [11], which also leads students to having the impression that STEM is about a factual recall, rather than understanding STEM's role in society, i.e. how STEM subjects are used in solving practical needs in different areas of industry and society. Students' motivation and interest in dealing with STEM remains relatively low because they struggle to link school STEM experiences to their lives, though they often are very skilled users of STEM products, especially mobile phones and computers.

\section{School policy and its impact on STEM teaching}

The above-mentioned findings point out the necessity to improve STEM education from the lower levels of schooling. In this aspect we are facing a very paradoxical situation which is true not only for Slovakia. As the official reports show [12], in most of the OECD countries the governments place enhancement of STEM education among the priorities of their national education policies. But this is not always backed up with the appropriate systematic support and corresponding investments, mainly at lower levels of education.

Reform steps carried out in many European countries within the context of the EU recommendations and the building of the knowledge society should contribute to the reinforcement and improvement of the technology education status in two aspects in relation to the status of the relevant school subjects within the curriculum as well as in relation to students' attitude to technology and science subjects. Unfortunately, it is not a rare case that the changes introduced within the reforms do not function in this way: they either do not fulfil the expectations or do not bring the intended improvement of the previous situation. In Slovakia, this was the case of the curricular reform introduced in 2008.

Before the reform, technology issues in the Slovak lower secondary schools were taught within the framework of the subject called technical education. The subject used to have a time allocation of 1 lesson per week in each grade (grades $6^{\text {th }}-9^{\text {th }}$ ). The reform changed the name of the subject to technology and cut its time allocation to a half of a lesson per week taught only in the $7^{\text {th }}$ and $8^{\text {th }}$ grades. At the same time, the schools were given a possibility to use so-called elective lessons to enhance the education in some areas; however, this additional allocation of extra time out of the elective lessons was based on the school managers' decision. This means that schools could support technical education either by including additional lessons for teaching technology or by incorporating some additional elective subjects related to technology (STEM) teaching. The content of the compulsory subjects was determined up to $70 \%$ by the State Education Programme ([13], [14] and 15]) and the remaining $30 \%$ was designed by schools in their School Education Programme. In this respect the 2008 reform in relation to technology education could be assessed both as negative and positive. But the issue is what really happened in practice, whether the elective lessons were used to support technology education or not.

During the period of the years 2013-2015 (following the implementation of the curricular reform in all grades of the lower secondary education which was finished in 2012) the research aimed at analysing the curricular reform impact on technology education at schools was carried out ([16] and [17]). The researchers found out that despite the general strengths of the curricular reform, its impact on technical education at schools was significantly negative. The curricular reform reduced the compulsory number of lessons allocated to teaching technology and the possibility to increase the compulsory number of lessons by adding some of the elective lessons to teaching technology was used only in $22 \%$ of schools. In addition to that, $12 \%$ of schools introduced extracurricular activities focusing on technology for their students. But even the sum of these two figures cannot be assessed as a positive impact of the reform on technology education.

Another striking fact is that within the introduction of the curricular reform no official statement was issued which would show a state strategy regarding the role of technology education at schools and no measures were introduced to support the establishment of material and technical conditions adequate for technology teaching. This was done only in May 2012 in the frame of the Manifesto of the Government of the Slovak Republic [18], in which the government introduced draft measures to enhance vocational training and education. In the Manifesto the government stated also the need to reinforce teaching maths, 
science and technical subjects. Following the Manifesto and the constantly growing criticism of vocational training and education expressed by employers, the Ministry of Education, Science, Research and Sport of the Slovak Republic initiated a national project financed by the EU Support for professional orientation of pupils of primary and lower secondary school to vocational education and training through the development of polytechnic education aimed at developing work skills and work with talents (so-called Workrooms project [19]). Though its implementation started only in April 2013, i.e. 6 years after the beginning of the curricular reform implementation, it was perceived as a support means to the reform and it received a very positive feedback.

The project objective was to help solving the alarming situation in students' choice of secondary school depending on the profession they have chosen. As a result of the state education policy during the last two decades (or rather as a result of the absence of any long-term concept of this policy) we are currently facing evident lack of students' interest in studying at secondary vocational schools. Consequently, this situation still leads to the increasing lack of qualified work forces on the labour market [20], as majority of pupils prefer to study at comprehensive grammar schools though those schools do not prepare them for any expert performance in any particular profession.

\section{Lack of teachers with STEM major qualification}

In the context of the continually decreasing youth's interest in STEM education, the OECD calls attention to the issues of the qualification of teachers teaching science and technology subjects. These teachers are often qualified in other major subjects but due to the lack of teachers with relevant qualification in teaching natural science subjects they are obliged to teach subjects for which they do not have adequate competencies [12].

An integral part of the above-mentioned analysis of the curricular reform impact on technology education in Slovak schools in 2013-2015 was also the issue of qualified teaching of the subject technology, i.e. finding what percentage of teachers teaching the subject in lower secondary schools is qualified to teach it [16]. In order to map the extent to which teaching technology education (school subject technology) is ensured by qualified teachers and to find what the length of their teaching at schools is, the research data from both head-teachers and teachers were collected. The findings are presented in a graphic form in Fig. 3.

The graphical data presented in Fig. 3 show an alarming finding that almost $50 \%$ of teachers qualified to teach technology belong to the category of teachers with more than 25 years of teaching practice. These teachers entered their pedagogical career before the year 1989 . The data also implicitly show the radical decrease of students' interest in studying technology as one of the major subjects in teacher training programmes; and as seen in Fig. 3 (from right to left), the trend still increases. The cut down of the compulsory lessons allocated to technology in the introduced curricular reform has by no means contributed to the improved status either of the subject or of the technical education in general.

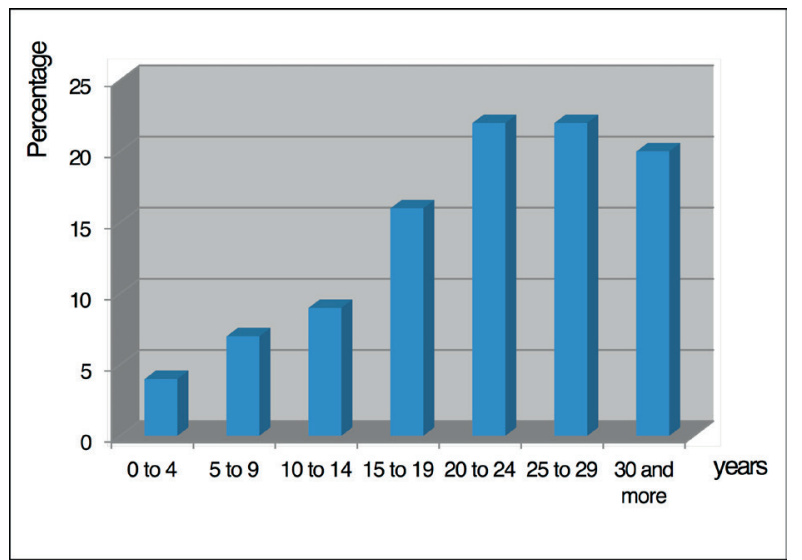

Fig. 3 Qualified technology education teachers at schools and the length of their teaching practice (Source [16])

As it follows from the analysis of the length of teaching practice of technology teachers currently employed at schools, their number will be decreasing in the next years as a consequence of their retirement. This means that the already alarming ratio (58\% : $42 \%$ ) will very quickly change "in favour" of the unqualified teachers as there is no platform in the society which would enable a smooth substitution of the leaving teachers; the interest in technology teacher training programmes is minimal. Even if some systematic steps were immediately taken to increase the interest in this study, their first results would be visible only in five years after their introduction (i.e. in the time needed for the standard length of teacher training study programmes).

Another alarming finding is the fact that in one third of the schools (34\%) no qualified technology teacher is among the school staff. In the other schools (59\%) there are mostly one or two qualified teachers among the staff ( $42 \%$ and $17 \%$ respectively). Three and more technology teachers in a school are a very rare case (5\%).

The analysis of the number of qualified technology teachers in schools in relation to their size showed that the worst situation is in small schools. At least one qualified technology teacher can be found in $52-56 \%$ of small schools (with the number of students up to 200), in three quarters ( $75 \%$ ) of middle sized schools (with the number of students from 201 to 400 ) and in $84 \%$ of big schools (with more than 400 students).

Taking into consideration a small number of lessons allocated to the subject technology education in the past and their cut down for teaching technology as introduced in the current curricular 
reform (compulsory lessons allocated by the State Educational Programme), even big schools do not need more qualified technology teachers. The situation in the past and the curricular change have caused particularly low demand for technology teachers on the labour market which, together with the highly demanding study programme in technology teacher training, may have been the factors significantly contributing to a low and constantly decreasing interest in technology teacher training study programmes in the past 20 years (see the data on numbers of qualified technology teachers with the length of teaching practice under 20 years in Fig. 3).

Although the reform has introduced a possibility to increase the number of lessons for technology education through the use of the elective lessons, it would be, in principle, irresponsible from the head teachers to take the decision on increasing the number of lessons allocated to technology teaching without having enough qualified teachers to teach it. Thus, the lack of qualified technology teachers together with the absence of classrooms (workrooms) with special equipment for technology teaching and the low status of the subject have caused, as mentioned above, that only $22 \%$ of schools have used this possibility.

\section{Regional differences in the approach to teaching technology}

Further analyses were done with the focus on differences in teaching technology in different regions of Slovakia.

As to the numbers of qualified technology teachers, the worst situation was indicated in Bratislava, Trencin and Nitra regions (the highest percentage of schools without any qualified technology teacher). For most of the regions of Slovakia an "average state" is typical. This means one qualified technology teacher per school in average (Banska Bystrica, Trnava, Zilina, Kosice and Presov regions). Schools with more than one qualified technology teacher are very rare and they are located mostly in Kosice and Presov regions.

To analyse the regional differences in the approach to teaching technology, semi-structured interviews with research sample of technology teachers from Bratislava and Presov region were carried out [21].

The research was aimed at finding out the opinions and experiences of teachers regarding teaching technology. The key question of the carried out interviews was examining the respondents' opinions about pros and cons of teaching technology. The comparison of the findings from the qualitative analysis of the recorded interviews with respondents from Bratislava and Presov regions indeed proved differences in their approach to teaching the subject. The core difference was well-turned in a statement of one of the respondents: "I taught also far away from Bratislava. The support given to technology teaching was much bigger there." Based on the data from the semi-structured interviews with technology teachers, the open criticism and refusal of this school subject is typical for Western Slovakia (Bratislava region). In Eastern Slovakia (represented by Presov region), higher acceptance of the subject is evident. Even though the teachers' attitude to the subject is quite critical there, too, they are aware of the lack of teaching materials and material equipment necessary for technology teaching, they are trying to find their own way to teach technology in particular conditions of their schools. While in Bratislava region there is a tendency to give preference to foreign language teaching and to put technology aside (or even some disinterest, apathy and resignation), in Presov region an ambition and effort of teachers to activate students and ensure for them various materials is evident. A rather frequent opinion in Presov region is that technology should be taught with an increased time allocation. On the contrary, school management in Bratislava region in most cases perceives technology as a supplementary subject which had its justification in the past (because of the handicrafts and technical skills) but nowadays it has lost its justification. An example of such opinion can be the following statement: "Why should we produce anything? We, in Bratislava can buy anything at a Chinese shop. Let technology ad handycrafts be taught elsewhere, for us, in the capital city, it has no sense. Technology should be just an optional subject." But at the same time the teachers point out the fact that children and young people are unable even to hit a nail with a hammer; they are mastering mobiles and computers but losing common manual skills.

The approach of students' parents to teaching technology is also significantly different in the referred regions. This is reflected in their co-operation with schools when it comes to teaching this subject. They do not support schools' effort to ensure relevant conditions for teaching technology. It is not a rare case that they even refuse to provide any necessary materials their children need for technology lessons. In the cases of cleaning the school premises a criticism occurs why their child should work manually, after all $\mathrm{s} / \mathrm{he}$ is assigned to become a lawyer or a doctor.

\section{Conclusion}

The above-presented and discussed research results show, in an indirect way, how the new living conditions influence the values accepted by the young generation, revealing at the same time also their interests and professional orientation. Paradoxically, the state school policy declares the support of the government for technology education but in practice we are confronted with negative approaches to the professional careers related to technology and manual or technological skills. 


\section{References}

[1] OECD: Encouraging Student Interest in Science and Technology Studies. Paris : OECD, 2008. ISBN 978-92-64-04069-4.

[2] JOYCE, A., DZOGA, M.: Science, Technology, Engineering and Mathematics Education: Overcoming Challenges in Europe. European Schoolnet : 2011. ISBN 9789491440144

[3] HASKOVA, A., ZAHOREC, J.: Analysis of Interest in Natural Science Subjects - as a Precondition of Development of University Education in Technical Branches. Perspective in Education Process at Universities with Technical Orientation in Visegrad Countries. Nitra : SPU, 2008, 34-39. ISBN 978-80-552-0148-1.

[4] LUKACOVA, D.: Attitudes of Lower Secondary School Students to Technology Education (in Slovak). Technické vzdelavanie ako sucast vseobecneho vzdelavania, Banska Bystrica : UMB, 2009. ISBN 978-80-8083-878-2.

[5] ZAHOREC, J., HASKOVA, A., MUNK, M., BILEK, M.: Tertiary Economy and Managerial Study Fields and Issues of Science Education Aimed at Database Systems. J. of Baltic Science Education, vol. 14, No. 4, 2015, 535-555. ISSN 1648-3898.

[6] EC: Eurobarometer 2006: Public Opinion in European Union. EC, 2007. Available at: http://ec.europa.eu/public_opinion/archives/ eb/eb66/eb66_en.pdf.

[7] VAlCOVA, K., PAVlikova, M., ROUBAlOVA, M.: Religious Existentialism as a Countermeasure to Moralistic Therapeutic Deism. Communications - Scientific Letters of the University of Zilina, vol. 16, No. 3, 2016, 98-104. ISSN 1335-4205.

[8] KONDRLA, M., PAVLIKOVA, M.: From Formal Ethics to Existential Ethics. European J. of Science and Theology, vol. 12, No. 3, 2016, 101-111. ISSN 1841-0464.

[9] VALCO, M., KRALIK, R., BARETT, L.: Morals Implications of Augustine's Philosophical and Spiritual Journey in his Confessiones. Communications - Scientific Letters of the University of Zilina, vol. 17, No. 2, 2015, 103-108. ISSN 1335-4205.

[10] PHANG, F. A., ABU, M. S., ALI, M. B., SAlleH S.: Faktor Penyumbang Kepada Kemerosotan Penyertaan Pelajar Dalam Aliran Sains: Satu Analisis Sorotan Tesis, Contributing factors to the decline in student participation in Science Stream: A Thesis Highlights Analysis, Skudai : Universiti Teknologi Malaysia, 2012.

[11] SIEW, N. M., AMIR, N., CHONG, CH. L.: The Perceptions of Pre-Service and In-Service Teachers Regarding a Project-Based STEM Approach to Teaching Science. SpringerPlus, vol. 4, No. 8, 2015. doi: 10.1186/2193-1801-4-8. Available at: http://www. springerplus.com/content/4/1/8

[12] OECD: Evolution of Student Interest in Science and Technology Studies: Policy Report. OECD, 2006. Available at: http://www.oecd. org/science/sci-tech/36645825.pdf.

[13] Law No 245/2008 on Education. Available at: https://www.minedu.sk/data/att/10246.pdf.

[14] SVP ISCED 1: State Educational Program for the First Stage of Basic Education (ISCED 1), Educational Area: A Man and the World of the Work (in Slovak). Available at: http://www.statpedu.sk/sites/default/files/dokumenty/statny-vzdelavaci-program/isced1_spu_ uprava.pdf

[15] SVP ISCED 2: State Educational Program for the Second Stage of Basic Education - Lower Secondary Education (ISCED 2), Educational Area: A Man and the World of the Work (in Slovak). Available at: http://www.statpedu.sk/sites/default/files/dokumenty/ statny-vzdelavaci-program/isced2_spu_uprava.pdf

[16] HASKOVA, A., BANESZ, G.: Technology at Lower Secondary Schools - Yes or Not (in Slovak). Praha : Verbum, 2015. ISBN 978-8087800-31-7.

[17] BANESZ, G.: Assessment of the Key Attributes of the Curricular Reform from the Teachers' Point of View (in Slovak). Technika a vzdelavanie / Technology and education, vol. 4, No. 2, 2015, 8-11, ISSN 1339-9888.

[18] Manifesto of the Government of the Slovak Republic. Available at: http://www.vlada.gov.sk/programove-vyhlasenie-vlady-sr-naroky-2012-2016/.

[19] SIOV: National Project Supporting Professional Orientation of Primary School Pupils to Vocational Education and Preparation through Development of Polytechnic Education Focused on Development of Working Skills and Work with Talent (in Slovak). Available at: http://www.zsodborne.sk/index.php/o-projekte/o-projekte.

[20] LUKACOVA, D.: Company Requirements on Graduates (in Slovak). Trends in Education, vol. 7, No. 1, 2014, 345-348. ISSN 1805-8949.

[21] MANDULAKOVA, S.: Regional Differences in Education of Technology (in Slovak). Vzajomna informovanost - cesta $k$ efektivnemu rozvoju vedecko-pedagogickej cinnosti / Informing each other - a way to effective development of science and teaching activities, Nitra : PF UKF, 2016, 32-39. ISBN 978-80-558-1094-2. 